\title{
A cross sectional study on the seroprevalence of bovine brucellosis in Al-Najaf province in Iraq
}

\author{
K.Z. Al-Alo $₫$ and A.J. Mohammed \\ Department of Veterinary Clinical Sciences, College of Veterinary Medicine, University of Kufa, Kufa, Iraq
}

\begin{tabular}{l} 
Article information \\
\hline Article history: \\
Received May 19, 2020 \\
Accepted May 4, 2021 \\
Available online October 1,2021 \\
\hline Keywords: \\
Brucellosis \\
Cattle \\
Rose Bengal \\
c-ELISA \\
Al-Najaf \\
\hline Correspondence: \\
K.Z. Al-Alo \\
khaleelz.khaleel@ uokufa.edu.iq
\end{tabular}

Article information

Article history:

May 19,20

Accepted May 4, 202

khaleelz.khaleel@uokufa.edu.iq

\begin{abstract}
Brucellosis is an endemic disease in many countries of the middle east including Iraq, despite the high attempts to control the disease in animals using vaccination programs. The study was conducted from January to March 2012, to determine the prevalence of bovine brucellosis in the Al-Najaf province in Iraq, which represent risk factors associated with brucellosis in cattle. Blood samples were collected from 172 cows and 15 bulls of 20 dualpurpose cattle herds. Serological examinations are the most useful and widely used tool for the diagnosis of brucellosis in man and animals. All animal serum samples were tested by the Rose Bengal plate test (RBT), and the positive cases were confirmed by competitive enzyme-linked immunosorbent assay (c-ELISA). The overall prevalence of brucellosis was $5.81 \%$ divided between $5.81 \%$ in females and $0 \%$ in males, and $40 \%$ as herd numbers level. Females showed a higher seropositive reaction to the disease than males. In conclusion, this study demonstrated the presence of the disease and detected the seropositive reactions in animal samples in different farms of the province, with a difference in infection rate regarding the risk factor. Sanitary measures must be taken to avoid the occurrence and spread of the disease in humans and animals.
\end{abstract}

DOI: $10.33899 /$ ijvs.2021.127143.1471, CAuthors, 2021, College of Veterinary Medicine, University of Mosul.

This is an open access article under the CC BY 4.0 license (http://creativecommons.org/licenses/by/4.0/).

\section{Introduction}

Brucellosis is a bacterial infectious disease caused by the gram-negative Brucella species, that can affect domestic, wild animals as well as humans (1). Brucellosis can cause considerable economic losses in livestock production which have been estimated at 7-12 million dollars per each year (2). In Iraq, several studies have been carried out on brucellosis seroprevalence (3). In Mosul city, seroprevalence rate was $18.25 \%$ and $5.8 \%$ in cattle (4), and $8.50 \%$ in buffalo (5). In the camel, the prevalence rate was $16.29 \%$ in Wasit province (6), and 8.6\% in Erbil province (7). In Mosul province, the infection rate of ovine brucellosis was $15.9 \%$ using the ELISA test on different samples of sheep herds (8) and $25.6 \%$ using Rose Bengal test and 2- mercaptoethanol test in goats (9). In cattle, abortion is presented as the main clinical manifestation of the disease with B. abortus strain (10). Potential predisposing and risk factors include the climatic conditions, geographical region, animal species, sex, age, compliance with sanitary measures, such as milk and dairy products pasteurization, disposal of an aborted fetus (11). In Mosul city, Al-Iraqi reported a seroprevalence of Brucella antibodies in female buffalo $50.8 \%$ and $28.8 \%$ by using cELISA and RBT respectively (5). Another study showed that the seroprevalence of Brucella antibodies in cattle was $16.7 \%$ and $18.3 \%$ by using c-ELISA and RBT respectively (12).

The objective of this study was to determine the prevalence of bovine brucellosis in Al-Najaf province in Iraq.

\section{Materials and methods}

\section{Study area and population}

The seroprevalence of Brucellosis was performed in clinically healthy 198 animals 172 cows, 15 bulls aged more 
than 36 months, on 20 dual purpose cattle herds in Al-Najaf province during the period January - March 2012 was used in this study. The number of examined animals represents $1.01 \%$ of the cattle population in the province.

\section{Sample collection and study design}

Blood samples were collected from the coccygeal vein of 198 (172 cow, 15 bulls) clinically healthy animals. Serum was separated by centrifugation of blood sample at 2000 $\mathrm{rpm} / 5 \mathrm{~m}$ and kept at $-20^{\circ} \mathrm{C}$. All samples were labeled with sampling date, animal age, and sex.

\section{Serological test}

Antibodies against Brucella spp. were detected by the Rose Bengal test using a commercially available test kit (RBT; VIRCELL, Granada, Spain). Competitive ELISA test was used to confirm the positive results of Rose Bengal (Synbiotics $\left.{ }^{\circledR}\right)(13)$. The kits were used as directed by the manufacturer and all tests were performed by using (Bio-Tek Instruments, Inc. ELX-800). The dye of Rose Bengal is buffered at PH $3.65 \pm 0.05$, because the low $\mathrm{pH}$ reduces the nonspecific agglutination of smooth Brucella antigens and favors the activity of antibodies especially the IgG1 isotype.

\section{Statistical analysis}

Data obtained from the study were expressed as mean \pm standard error of the mean (mean \pm SEM) and analyzed using the SPSS software package (Version 16). One-way ANOVA was used to compare the differences in the mean values between the male and female animals. Values of $\mathrm{P}<0.05$ were considered significant.

\section{Results}

The results showed that the overall prevalence in cattle would be $5.05 \%$, and the prevalence rate of the disease in screened bulls and cows was 0.0 and $5.81 \%$ respectively (Table 1). Our study showed that the positive cases of brucellosis were found to be present in eight herds from a total of twenty herds on the basis of Rose Bengal test and cELISA test, in which the general prevalence rate was $40 \%$.

Table 1: Seroprevalence rate of bovine brucellosis in cattle older than 36 months in Al-Najaf province

\begin{tabular}{lccccc}
\hline & Total number & Negative result No. & Positive result No. & Seroprevalence (\%) & P-value \\
\hline Female & 172 & 162 & 10 & $5.81 \%$ & 0.0254 \\
Male & 15 & 15 & 0 & $0 \%$ & 0 \\
\hline
\end{tabular}

\section{Discussion}

The results of the current study agree with the results of different studies of bovine brucellosis seroprevalence. The different condition of animal's husbandry included environmental factors, husbandry system, and management practices reveal the different percentage of infection with the disease (14).

There is a great difference in the infection rate of the disease in various Iraqi cities, and this runs in the same direction with the results gained by other researchers in the world.

It is mentioned that the disease prevalence differs markedly between countries and within the one country; this great difference belongs to many factors such as occupational, socioeconomic, and demographic factors. In the same city there are also changes in the rate of seroprevalence in animals in various areas (15).

In the studied area in Al-Najaf, the main factor for the prevalence rate is the contamination with uterine discharge, vaginal discharge, milk, aborted fetus, and semen of infected bulls. Feces of infected animals also considered as source of infection.

According to the sex of the animal, the prevalence rate of the disease in this study was $0 \%$ in males and $5.81 \%$ in females. There are significant differences between males and females in susceptibility towards the disease.
Anyway, there are different data regarding the disease prevalence in both animal sexes, and our results are consistent with the results of previous researchers, who recorded that the females are more susceptible to infection than males, whereas some scientists found that there is no apparent relation between sex of animal and susceptibility to Brucella infection (6). Other researchers suspected that ruminant's males are more affected by brucellosis than females (16).

As reported by different organizations such as OIE, FAO, and WHO, brucellosis is seemed to be one of the significant zoonotic in the world through ingesting of unpasteurized milk or dairy products of diseased animals (10).

Al-Hamdani and Al-Zawadi (17) mentioned that there is no difference between RBT, tube agglutination test, and 2mercaptoethanol, while other studies mentioned that the tube agglutination, rose Bengal and 2- Mercapto-ethanol tests performed by (18) was less accurate than the Indirect ELISA test.

On the other hand, more confirmatory tests in some epidemiological studies were used besides to confirmation of Brucella spp in culture (19).

In our study, all the serum samples were examined by the Rose Bengal test, then the positive samples were confirmed using the competitive ELISA test.

The c-ELISA test was used to overcome problems that came from residual antibodies, and cross-antigenicity 
between these bacteria and many Gram-negative bacteria (20).

Serological tests are safe, rapid, and somewhat inexpensive diagnostic tools; Rose Bengal test, enzymelinked immunosorbent assays, complement fixation test is advisable tests for large-scale eradication objectives $(21,22)$.

ELISA test used in this study as suggested by (23) to confirm and avoid many problems of other serological tests (24).

Also by using different serological tests, the variation between the results are depends on the serological test specificity and sensitivity. ELISA, low coast, quantitative, sensitive, but requires standardization of the antigen used. cELISA test has high sensitivity and specificity as a substitute to classical tests such as the Rose Bengal test, which is cannot differentiate between some strains like B. abortus strain 19 (25).

\section{Conclusions}

The result of this work provides another screening information for Brucellosis in cattle and gives a better epidemiological saw that could be used for better control of such an essential disease in Iraq.

\section{Acknowledgments}

The authors would like to thank the staff of College of Veterinary Medicine at Kufa University for helping during research.

\section{Conflict of interest}

No conflicts of interest regarding the publication of this manuscript.

\section{References}

1. Damena D, Duguma R. Seroprevalence of bovine brucellosis and associated risk factors in and around Alage district, Ethiopia. Springerplus. 2016;5:851. DOI: 10.1186/s40064-016-2547-0

2. Dahl MO. Brucellosis in food-producing animals in Mosul, Iraq: A systematic review and meta-analysis. PLoS One. 2020;15: 0235862. DOI: 10.1371 /journal.pone. 0235862

3. Dahl MO, Hamdoon OK, Abdulmonem ON. Epidemiological analysis for medical records of veterinary teaching hospital, University of Mosul during 2017 to 2019. Iraqi J Vet Sci. 2021;35:541-8. DOI: 10.33899/ijvs.2020.127141.1468

4. Al-Hankawe O KH, Al-Saad KA, Rhaymah MS. Diagnosis of bovine brucellosis in Mosul city by indirect ELISA and conventional serological tests. Iraqi J Vet Sci. 2010;24:1-6. DOI: 10.33899/ijvs.2010.5570

5. Al-Iraqi OM, Al-Hankawe OK, Abdul-Majeed MO, Al-Farwachi MI. Comparison between competitive elisa and rose-bengal tests in detection of brucella antibodies in buffalo sera in mosul city, Iraq. Basrah J Vet Res. 2009;8:93-7. [available at]

6. Hanon BM. Seroprevalence of brucellosis and toxoplasmosis in camels of Wasit Province, Iraq. Al-Qadisiyah J Vet Med Sci. 2017;16:29-37. DOI: $\underline{10.29079 / \text { vol16iss2art440 }}$
7. Al-Mashhadany DA. The significance of milk ring test for identifying brucella antibodies in cows and buffaloes' raw milk at Erbil governorate, Iraq. Iraqi J Vet Sci. 2019;33:395-400. DOI: 10.33899/ijvs.2019.163085

8. Al-Dabagh II, Jasim BM, Jarjees MT. Seroprevalence of antibodies to toxoplasmosis, brucellosis and chlamydiosis in abortive sheep in Nineveh governorate, Iraq. Iraqi J Vet Sci. 2014;28:21-5. DOI: 10.33899/ijvs.2014.89467

9. Ahmed IM, Al-Baroodi S, Al A, Al-Attar MY. Detection of antibodies level for goat brucellosis in Mosul, Iraq. Iraqi J Vet Sci. 2009;23:33-6. DOI: $10.33899 / \mathrm{ijvs} .2009 .5688$

10. Aparicio ED. Epidemiology of brucellosis in domestic animals caused by Brucella melitensis, Brucella suis and Brucella abortus. Rev Sci Tech Off Int Epiz. 2013;32:53-60. DOI: 10.20506/rst.32.1.2187

11. Kopper G, Mirecki S, Kljujev IS, Raicevic VB, Lalevic BT, JovicicPetrovic J. Hygiene in primary production. In: Food Safety Management. Elsevier; 2014; 559-621. [available at]

12. Al-Farwachi MI, Al-Iraqi OM, Al-Hankawe Ok, Abdul-Majeed MO. Using of competitive ELISA in detection of Brucella antibodies in cattle sera in Mosul city, Iraq. Iraqi J Vet Sci. 2009;23:97-103. [available at]

13. Ridhae KM and Hussein SA. Serological and molecular investigations of Brucellosis in dairy cows at certain areas of Al-Sulaymaniyah governorate- Iraq. Iraqi J Vet Sci. In Press. 2021. DOI: 10.33899/ijvs.2021.127688.1520

14. Njeru J, Wareth G, Melzer F, Henning K, Pletz MW, Heller R. Systematic review of brucellosis in Kenya: disease frequency in humans and animals and risk factors for human infection. BMC Public Health. 2016;16:853. DOI: 10.1186/s12889-016-3532-9

15. Salman SS, Mosa ST. Seroprevalence of ovine brucellosis in Baghdad province. Al-Anbar J Vet Sci. 2015; 8:36-41. [available at]

16. Khan MZ, Zahoor M. An overview of brucellosis in cattle and humans, and its serological and molecular diagnosis in control strategies. Trop Med Infect Dis. 2018;3:65. DOI: 10.3390/tropicalmed3020065

17. AL-Hamdani AH, AL-Zawadi NJ. Significant of conventional serological tests in diagnostic of Brucellosis in AL-Diwaniyah province. Al-Qadisiah Med J. 2014;10:98-103. [available at]

18. Shome R, Rao KN, Nagalingam M, Krishnamoorthy P, Krithiga N, Padmashree BS. Comprehensive approaches for diagnosis of human brucellosis. Indian J Comp Microbiol Immunol Infect Dis. 2013;34:3038. [available at]

19. Godfroid J, Nielsen K, Saegerman C. Diagnosis of Brucellosis in Livestock and Wildlife. Croat Med J. 2010; 51: 296-305. DOI: $10.3325 / \mathrm{cmj} .2010 .51 .296$

20. Mustafa AM, Ellah MRA, Elbauomy EEM, Sadiek AH. Comparative studies of different serological tests for diagnosis of brucellosis in vaccinated sheep with special reference to competitive ELISA. Vet Res. 2012;5:31-36. DOI: $10.3923 /$ vr.2012.31.36

21. Al-Wataar B, Lazim E, Al-Hyani $\mathrm{OH}$. Creatine kinase and $\mathrm{C}$ reactive protein as an indicator for tissue damage in the retained placenta in cows. Iraqi J Vet Sci. 2020; 35:163-167. DOI: 10.33899/ijvs.2020.126496.1338

22. Mahmoud MA, Ghazy AA, Shaapan RM. Review of diagnostic procedures and control of some viral diseases causing abortion and infertility in small ruminants in Egypt. Iraqi J Vet Sci. 2021;35:513521. DOI: $10.33899 /$ ijvs.2020.127114.1461

23. Bercovich Z, Güler L, Baysal T, Schreuder BEC, van Zijderveld FG. Evaluation of the currently used diagnostic procedures for the detection of Brucella melitensis in sheep. Small Rumin Res. 1998;31:1-6. DOI: 10.1016/S0921-4488(98)00111-4

24. Lucero NE, Escobar GI, Ayala SM, Lopez G. Sensitivity and specificity of an indirect enzyme-linked immunoassay for the diagnosis of Brucella canis infection in dogs. J Med Microbiol. 2002;51:656-60. DOI: $10.1099 / 0022-1317-51-8-656$

25. Gall D, Nielsen K. Serological diagnosis of bovine brucellosis: a review of test performance and cost comparison. Rev Sci Tech. 2004;23:9891002. [available at] 
لتحديد مدى انتشار مرض الإجهاض الساري في الأبقار في محافظة

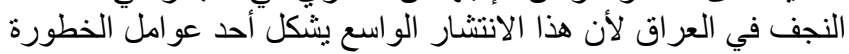

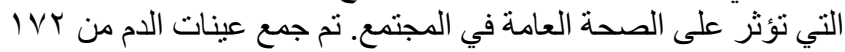

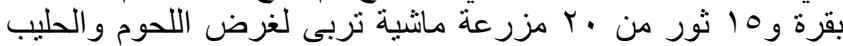

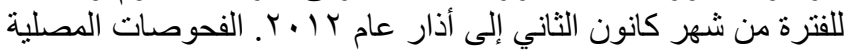

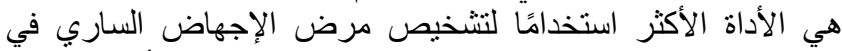

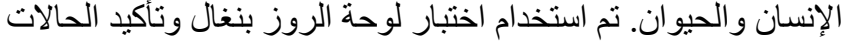

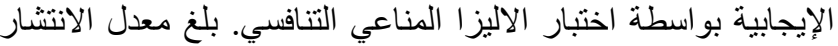

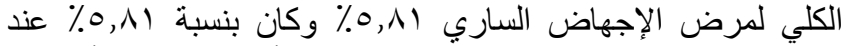

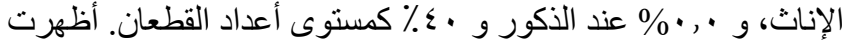

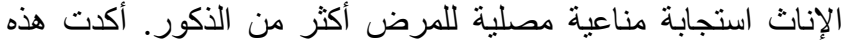

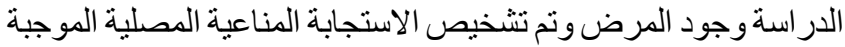

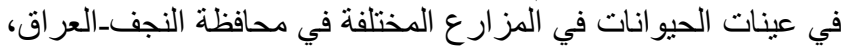

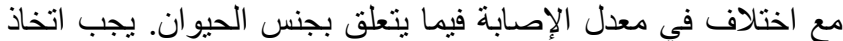
التدابير الصحية لتجنب حدوث و انتشار المرض في الإنسان والحيو النيان.
دراسة مقطعية_عرضية مسحية للانتشار المصلي لمرض الإجهاض الساري البقري في محافظة النجف في

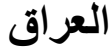
خليل زينل خليل العلو و أحمد جاسم محمد

فرع العلوم السريرية، كلية الطب البيطري، جامعة الكوفة، الكوفة،

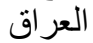

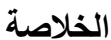

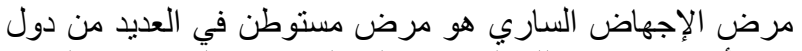

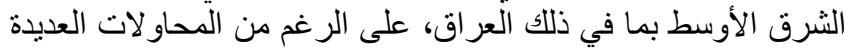

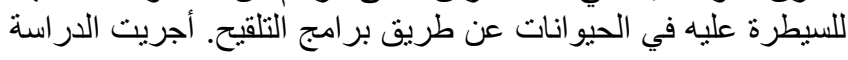

